\title{
Ar sausųjų miltelių inhaliatoriai, turintys itin smulkias aerozolio daleles, gali pagerinti vaisto depoziciją plaučiuose?
}

\author{
CAN DRY POWDER AEROSOLS, WHICH CONTAIN EXTRA-FINE DRUG PARTICLES, \\ IMPROVE DRUG DEPOSITION IN THE LUNGS?
}

\author{
LAIMA KONDRATAVIČIENE் \\ LSMU MA Pulmonologijos klinika
}

\begin{abstract}
Santrauka. Siekiant kuo geresnès astmos ir lètinès obstrukcinès plaučių ligos (LOPL) kontrolès, vis labiau didèja susidomėjimas itin smulkių dalelių aerozoliais, kurie nukreipti ị smulkiuosius kvèpavimo takus. İvertinus anksčiau paskelbtus vaistų depozicijos plaučiuose tyrimų duomenis, buvo pradèta aiškintis, ar dalelès, kurių skersmuo mažesnis nei $1 \mu \mathrm{m}$, gali pagerinti vaisto depoziciją periferiniuose kvejpavimo takuose. A. H. Boer apžvalgoje, ịvertinus daugelį tyrimų bei palyginus Symbicort ${ }^{\circledR}$ TurbuHaler ${ }^{\circledast}$, Seretide Diskus ${ }^{\circledast}$ ir Foster ${ }^{\circledR}$ NEXThaler ${ }^{\circledR}$ sausųjų miltelių inhaliatorius, ịrodyta, kad 1-3 $\mu$ m dalelès yra daug veiksmingesnès depozicijai plaučiuose.

Reikšminiai žodžiai: smulkieji kvėpavimo takai, smulkiųjų dalelių aerozoliai, depozicija plaučiuose, sausųjų miltelių inhaliatoriai.

Summary. There is increasing interest in the use of extra-fine particles aerosols to target the small airways in the management of asthma and chronic obstructive pulmonary disease (COPD). Using previously presented deposition data, it was unclear, whether particles less than $1 \mu \mathrm{m}$, can increase drug deposition in smaller airways. A. H. Boer manuscript summarizes and compares Symbicort ${ }^{\oplus}$ TurbuHaler $^{\oplus}$, Seretide Diskus ${ }^{\oplus}$, and Foster ${ }^{\oplus}$ NEXThaler ${ }^{\oplus}$ dry powder inhalers, and proved that particles in 1-3 $\mu \mathrm{m}$ diameter have significant deposition in lungs.

Keywords: small airways, small particles aerosols, deposition in the lungs, dry powder inhalers.
\end{abstract}

\section{IVADAS}

Astma ir lètinè obstrukcinė plaučių liga (LOPL) - tai obstrukcinès kvèpavimo takų ligos, kurioms būdingas lètinis kvèpavimo takų uždegimas. Dèl naujų vaistų bei jų derinių sukūrimo, ịkvejpimui skirtų prietaisų naujovių, šių ligų kontrolè pastaraisiais metais žymiai pagerejo. İkvepiamieji gliukokortikoidai (IGK) yra kertinis astmos gydymo pagrindas. Tuo tarpu LOPL medikamentinio gydymo pagrindas - ikvepiamieji ilgo veikimo $\beta_{2}$ agonistai (IVBA), o IGK pridedami prie IVBA derinyje, esant dažniems ligos paūmèjimams. Dèl to kuriama vis daugiau IGK/IVBA vaistų derinio inhaliatorių. Kadangi sukuriami vis naujesni inhaliatoriai, dažniau diskutuojama bei atliekama mokslinių tyrimų apie smulkiųjų kvėpavimo takų svarbą sergant astma ir LOPL.

\section{SMULKIŲJŲ KVĖPAVIMO TAKŲ SVARBA GYDANT OBSTRUKCINES PLAUČIŲ LIGAS}

Smulkieji kvejpavimo takai - tai kvėpavimo takai, kurių diametras yra mažesnis nei $2 \mathrm{~mm}$. Manoma, kad siekiant paveikti smulkiuosius kvèpavimo takus ir pasiekti geresnị vaistų pasiskirstymą visame bronchų medyje, gali prireikti smulkesnių dalelių aerozolių. Ši prielaida paskelbta dar 1990 m., kurioje chlorofluorokarbono (CFC) nešiklius turintys suslègto oro fiksuotu dozių inhaliatoriai (angl. pressurized metered dose inhalers, pMDI), kurių sudètyje yra beklametazono dipropionatas (BDP), buvo pakeisti hidrofluoroalkano (HFA) nešiklius turinčiais pMDI, didèjant susirūpinimu aplinkos tarša (plonejjant ozono sluoksniui). Buvo i̇rodyta, kad HFA pMDI reikia tik pusès BDP dozès, lyginant su CFC pMDI, siekiant veiksmingesnio vidutinio sunkumo astmos gydymo. Šis rezultatas buvo priskirtas žymiai smulkesnėms HFA pMDI aerozolio dalelèms, kurių atitinkamas vidutinis aerodinaminis skersmuo (angl. mass median aerodynamic diameter, MMAD) yra 1,1 $\mu \mathrm{m}$, lyginant su CFC pMDI dalelèmis, kurių MMAD - 3,5-4 $\mu \mathrm{m}$.

Vienintelis IGK/IVBA derinys, išskiriantis smulkiąsias ịkvepiamojo vaisto daleles pMDI inhaliatoriuje, o dabar ir sausųjų miltelių inhaliatoriaus (angl. dry powder inhaler, DPI) pagrindu, yra beklametazono dipropianato/ formoterolio (BDP/F) derinys, daugumai žinomas kaip Foster ${ }^{\oplus}$. Pastebèjus didelę itin smulkių HFA pMDI įkvepiamųjų dalelių naudą, buvo tikètasi, kad tokį pat gerą rezultatą galima pasiekti ir su sausųjų miltelių mažų dalelių inhaliatoriumi, koks yra naujasis 


\section{Farmakoterapija}

Foster ${ }^{\circledast}$ NEXThaler ${ }^{\circledast}$ DPI, lyginant su kitų vaistų DPI tais pačiais deriniais. Buvo apžvelgti keli lyginamieji tyrimai su naujaisiais prietaisais bei padaryta išvada, kad gydant smulkiuosius kvèpavimo takus su mažesnèmis ịkvepiamosiomis vaisto dalelèmis, pasiekiamas geresnis rezultatas. Taip pat klinikiniais tyrimais įrodyta, kad IGK kasdienès dozès sumažinimas turèjo itaką geresnei astmos kontrolei bei gyvenimo kokybei.

\section{KAS YRA ITIN SMULKIOS VAISTO DALELĖS?}

Pirmasis ikkvépimui skirtas vaistas, formuojantis itin smulkias vaisto daleles, buvo beklametazonas pMDI inhaliatoriuje. Vaisto dalelių dydis $-1,1 \mu \mathrm{m}$, o įkvèpimo frakcija (t. y. kiek vaisto dalelių gali pasiekti alveoles) - apie 60 proc. Foster ${ }^{\oplus}$ NEXThaler $^{\oplus}$ DPI itin smulkių dalelių MMAD yra apibrěžiamas kaip 1,4-1,5 $\mu \mathrm{m}$. Itin smulkių ikvepiamujuc dalelių apibrèžimas mokslinèje literatūroje išplèstas iki $<2 \mu \mathrm{m}$ diametro. Tačiau yra ir prietaisų, kurie išskiria taip vadinamuosius itin smulkius aerozolius bei reikšmingas ịkvepiamųjų dalelių frakcijas, kurių dalelių diametras $>2 \mu \mathrm{m}$. Todèl, remiantis naujausiu apibrěžimu (diametras $<2 \mu \mathrm{m}$ ), visi šiuo metu prieinami MDI ir DPI įkvepiamieji vaistai susideda iš itin smulkių ir ne visiškai smulkių dalelių. Skirtumas yra santykinis kiekvienos šių dalelių (itin smulkių ir didesnių dalelių) frakcijos kiekis aerozoliuose. Taigi, polidispersinių aerozolių terminas „itin smulkus“ apibrèžiamas ne tik pagal dydị, bet ir pagal kiekybinę masę šiuose aerozoliuose.

Siekiant apibrèžti smulkiųjų dalelių struktūrą, jos suskirstomos į mažesnes nei mikrometras, o didesnès nei mikrometro dalelès išskiriamos ị dvi frakcijas: 1-3 $\mu \mathrm{m}$ bei $3-5 \mu \mathrm{m}$. Šis skirstymas suteikia daugiau informacijos apie smulkių dalelių struktūrą. $1 \mu \mathrm{m}$ dydis pasirinktas, nes dalelių, kurių diametras $<1$ $\mu \mathrm{m}$, depozicijos koncentracija yra žymiai mažesnè kvėpavimo takuose ir alveolèse atskirai, lyginant su didesnèmis nei mikrometras dydžio dalelèmis.

Depozicijai plaučiuose, lyginant skirtingus inhaliacinius prietaisus, svarbi ir kitų veiksnių ịtaka. Vaisto dalelių pasiskirstymą ir depoziciją plaučiuose lemia ne tik dalelių dydis, bet ir jų greitis bei buvimo laikas plaučiuose. Skirtumas tarp BDP CFC ir BDP HFA suděčių, anksčiau aprašytuose MDI tyrimuose, priklauso ne vien nuo dalelių dydžio, bet labiau nuo jų greičio, kuriuo aerozolis išskiriamas per kandiklį. Mažesnis HFA aerozolių srauto greitis sumažina smūgio jẻgą, taip sumažindamas vaisto kaupimąsi burnaryklèje. BDP HFA inhaliatoriuje (kai MMAD yra apie1,1 $\mu \mathrm{m}$ ) depozicija burnoje buvo pastebèta žymiai mažesnè (30 proc.), lyginant su CFC prietaisu (94 proc., kai MMAD yra apie 3,5-4 $\mu \mathrm{m}$ ). Taigi, galima daryti išvadą, kad žymiai didesnè dozès frakcija lieka prieinama bendrai depozicijai plaučiuose.

\section{INHALIATORIŲ SKIRTUMAI IR TECHNINĖS SAVYBĖS}

Inhaliatoriai, siekiant ištirti smulkių dalelių aerozolių naudą ir palyginti juos įvairiuose klinikiniuose tyrimuose, paprastai skiriasi ne tik išskiriamų dalelių dydžiu arba greičiu, bet ir jų tipu (DPI ar MDI), juose esančių vaistų koncentracija bei inhaliacinèmis technikomis. Daugelis klinikinių tyrimų vykdomi neatsižvelgiant ị inhaliacinę techniką bei pauzių trukmę, kurių metu sulaikomas kvejpavimas. Skirtingas inhaliatoriaus pasipriešinimas oro srovei gali lemti didelius ikvepiamo vaisto skirtumus netgi esant tokiai pačiai ¡kvvepimo jègai. Šis veiksnys gali būti lemiamas vaisto pasiskirstymui ir depocizijai plaučiuose, o akivaizdūs skirtumai - klinikiniam veiksmingui, šiems aerozoliams esant visiškai tokiems patiems in vitro. Keli veiksniai gali būti susiję ir su pačiu pacientu. Pavyzdžiui, netaisyklingas inhaliatoriaus naudojimas, motyvacijos stygius, vaisto tinkamumas arba ligos sunkumas (nepakankamas ikvejpimas, esant prastai plaučių funkcijai). Apibendrinus visus šiuos veiksnius, yra labai sudètinga apibrèžti, kuris yra svarbiausias siekiant gero klinikinio poveikio. Taigi, klinikiniai tyrimai pakankamai prastai rodo inhaliatoriaus savybes, kai kalbama apie aerozolio daleles ir patekimą i plaučius. Todèl reikalingas kitoks požiūris, siekiant ištirti, ar mažesnès nei mikrometro dalelès gali prisidèti prie geresnio klinikinio poveikio. Inhaliatoriaus savybès ir su pacientu susiję veiksniai, tokie kaip inhaliavimo technika, depozicija plaučiuose, aerozolio dalelių dydis ir jų pasiskirstymas skirtingose kvépavimo takų dalyse turi būti apsvarstyti atskirai, kaip vienas kitam itakos nedarantys veiksniai.

Vertinant inhaliatorių geriausio klinikinio poveikio aspektu, turi būti pradedama nuo aerozolio savybių, kurios turi ittakos srovés greičiui. Klinikiniais tyrimais siekiama išsiaiškinti, ar dalelès, mažesnès nei mikrometras, gali pagerinti vaisto depoziciją plaučiuose. Taip pat svarbu išsiaiškinti, kokio diapazono aerodinaminio diametro dalelès turi didžiausią depoziciją plaučiuose. Paskutinis tikslas - įvertinti išskiriamas smulkiąsias daleles jau esamuose IGK/IVBA derinių DPI inhaliatoriuose, lyginant juos su prieš tai išvardytais tikslais. Trys DPI IGK/IVBA derinių inhaliatoriai buvo testuojami trijuose slègio taškuose, siekiant išmatuoti jų išskiriamas smulkiụjų dalelių dozes (angl. fine particle doses, FPD) ir jų struktūrinius savitumus srovès greičiui. Mažesnè nei $1 \mu \mathrm{m}$ smulkiųjų dalelių frakcija (angl. fine particle fraction, FPF) buvo apskaičiuota siekiant išsamesnès informacijos apie mažesnių nei mikrometras dalelių buvimą ir kiekị aerozolyje. Išsami informacija apie išskiriamų FPF dalelių skirtumus $(<5 \mu \mathrm{m})$ ir aerozolių struktūrą $(\mathrm{FPF}<1,1-3$ ir 3-5 $\mu \mathrm{m}$ ), taip pat kaip ir srovés greitis, kuriuo aerozolis yra pernešamas ị kvejpavimo takus, yra reikalingi tam, kad būtų galima nuspręsti, ar klinikinio poveikio skir- 
tumai yra kurio nors veiksnio (arba jų derinio) rezultatas, ar gal yra kitų, mums dar nežinomų parametrų, mechanizmų, kurie gali turèti tam įtakos.

Atlikta įvairių DPI tyrimų in vitro. DPI tyrimai gali turèti labai skirtingus aerozolių savybių skirtumus, tačiau daugelio tyrimų rezultatai negali būti lyginami tarpusavyje dèl skirtingų testavimo sąlygų, duomenu apdorojimo bei jų pateikimo. A. H. Boer klinikinèje apžvalgoje buvo lyginamas geriausiai ị kvejpavimo takus patenkančių dalelių dydžio pasiskirstymas ir jų galima depozicija plaučiuose. Buvo ištirti trys IGK/IVBA vaistų deriniai DPI tiksliai tokiomis pačiomis sąlygomis (srauto greitis, esant 2, 4 ir $6 \mathrm{kPa}$ ), o duomenų pateikimui naudoti tokie patys parametrai, t. y. apskaičiuotu išskiriamų aerozolių dalelių masès frakcijos dydžiai, esantys ribose $<1,1-3$ ir 3-5 $\mu \mathrm{m}$. Šiam tyrimui nebuvo vartojamas MMAD terminas, nes MMAD nesuteikia informacijos apie aerozolio dydžio pasiskirstymą arba frakcijos dozès dydị (arba masę). MMAD buvo išskaičiuota tik $\mathrm{FPF}<5 \mu \mathrm{m}$ pasiekus $4 \mathrm{kPa}$ (1 lentelè).

O. S. Usmani su bendraautoriais išmatavo radioaktyviai pažymètų monodispersinių salbutamolio dalelių depoziciją plaučiuose $(1,5,3,0$ ir $6,0 \mu \mathrm{m})$ pacientams, sergantiems gerai kontroliuojama astma, esant skirtingiems ikvepiamos srovès greičiams. Jie taip pat išmatavo iškvèptų dalelių masės dalị (1 pav.). Kadangi šie mokslininkai tyrẻ tik tris atskirus dalelių dydžius, gauta informacija yra pakankamai ribota, kai kalbama apie daleles, mažesnes nei mikrometras.

\section{VAISTO DALELĖS DYDŽIO SVARBA}

Vaisto depozicinè dozè plaučiuose priklauso nuo ¡kvepiamos dozès ì plaučius, kurios dalis yra prarandama jai nusèdus burnarykleje bei iškvépimo metu. Dalelių depozicijos tikimybẻ burnaryklèje gali būti apskaičiuojama poveikio parametru (angl. impaction parameter, IP), kuris susideda iš dalelès tankio (angl. density, $\rho$ ), diametro skersmens (angl. diameter, D) ir jos greičio (angl. velocity, U) matmenų. Praktikoje srovès greitis (angl. flow rate, $\Phi$ ) gali būti naudojamas apskaičiavimams vietoje greičio matmens, kai tiems patiems eksperimentams naudojamas tas pats inhaliatorius ir išlaikomas linijinis proprorcingumas tarp U ir $\Phi$.

O. S. Usmani su bendraautoriais tyrimuose naudojo monodispersines daleles $(\rho=1)$, kai jų aerodinaminiai diametrai buvo 1,5, 3,0 ir 6,0 $\mu \mathrm{m}$. Kadangi buvo pateikti vidutiniai šių dalelių ịkvépimo srautai, vidutinės jų aerozolių IP reikšmės galèjo būti apskaičiuotos. Ryšys tarp apskaičiuotų IP parametrų ir eksperimento metu gautos depozicijos burnaryklejje reikšmių (2 pav.) leidžia realiai ivvertinti depoziciją burnaryklèje esant mažesnio skersmens dalelèms (1 pav.). Naudojant ši ryši, depozicija burnaryklejje buvo įvertinta esant dalelių diametrui: 0,6, $0,8,1,0$ ir $1,25 \mu \mathrm{m}$, kai srovés greitis $31 \mathrm{l} / \mathrm{min}$ ir $67 \mathrm{l} / \mathrm{min}$.

Mažos dalelès $(\mathrm{D}<1-2 \mu \mathrm{m})$ pirmiausia nusèda sedi-
1 lentelè. Smulkiujų dalelių, išskirtụ dydžių frakcijomis, pasiskirstymas procentais plaučiuose, kai slègis $4 \mathrm{kPa}$

\begin{tabular}{|c|c|c|c|}
\hline \multicolumn{5}{|c|}{ IGK } \\
\hline Frakcija & $\begin{array}{c}\text { SY-TU } \\
\text { Budezonidas }\end{array}$ & $\begin{array}{c}\text { SE-DI } \\
\text { Flutikazonas }\end{array}$ & $\begin{array}{c}\text { FO-NE } \\
\text { BDP }\end{array}$ \\
\hline$<1 \mu \mathrm{m}$ & 6,5 & 1,6 & 18,9 \\
\hline $1-3 \mu \mathrm{m}$ & 29,1 & 13,9 & 22,2 \\
\hline $3-5 \mu \mathrm{m}$ & 12,7 & 8,2 & 4,3 \\
\hline $1-5 \mu \mathrm{m}$ & 41,8 & 22,1 & 26,5 \\
\hline$<5 \mu \mathrm{m}$ & 48,3 & 23,7 & 45,4 \\
\hline MMAD $(\mu \mathrm{m})$ & 2,07 & 2,54 & 1,21 \\
\hline \multicolumn{5}{|c|}{ IVBA } & SE-DI & FO-NE \\
\hline Frakcija & SY-TU & Salmeterolis & Formoterolis \\
\hline$<1 \mu \mathrm{m}$ & 6,7 & 1,5 & 15,6 \\
\hline $1-3 \mu \mathrm{m}$ & 25,6 & 12,8 & 29,0 \\
\hline $3-5 \mu \mathrm{m}$ & 12,2 & 7,3 & 5,7 \\
\hline $1-5 \mu \mathrm{m}$ & 37,8 & 20,1 & 34,7 \\
\hline$<5 \mu \mathrm{m}$ & 44,5 & 21,6 & 50,3 \\
\hline MMAD $(\mu \mathrm{m})$ & 1,96 & 2,36 & 1,57 \\
\hline
\end{tabular}

Santrumpos: BDP -beklametazono dipropianatas; FO - NE - Foster ${ }^{\oplus}$ NEXThaler ${ }^{\oplus}$; IGK - inhaliuojamieji gliukokortikoidai; IVBA -ilgo veikimo $\beta_{2}$ agonistai; SE - DI - Seretide ${ }^{\circledast}$ diskas; SY - TU - Symbicort ${ }^{\circledast}$ TurbuHaler $^{\oplus}$.
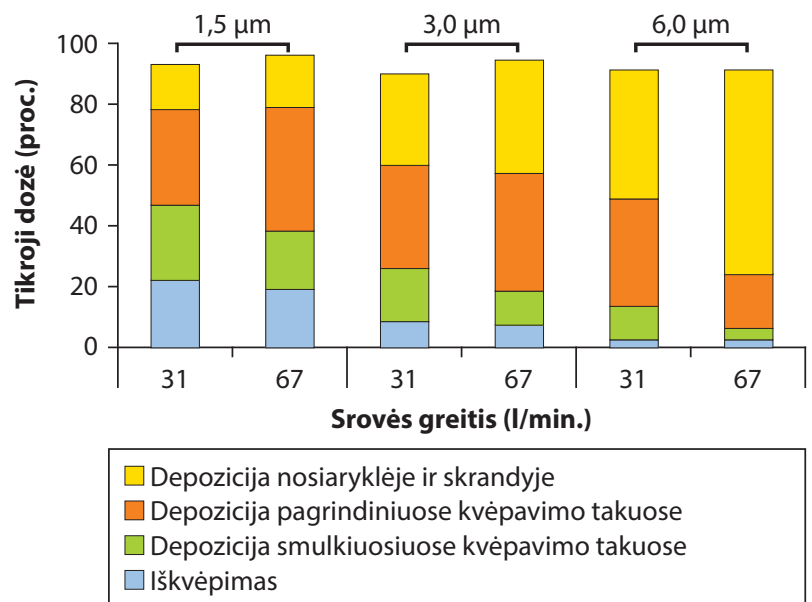

1 pav. Dalelès dydžio veiksmingumo ir ịkvèpimo srovès greičio įtaka vaisto depozicijai plaučiuose, tiriant monodispersines daleles

mentacijos būdu plaučių periferijoje. Sedimentacijos tikimybė priklauso nuo galinio dalelès nusėdimo greičio (UTS), dalelès atstumo (H) iki kvèpavimo takų sienelès bei laiko, kuris skirtas nusèdimui (t). Siekiant pagerinti mažų dalelių nusėdimą kvėpavimo takuose, turi būti didinamas jų išbuvimo laikas periferiniuose kvẻpavimo takuose (pvz., prailginus kvėpavimo sulaikymo pauzę po gilaus ikvèpimo). Jei atstumas $(\mathrm{H})$ yra didesnis nei laiko, skirto dalelès nusèdimui, ir galinio nusėdimo greičio $\left(H>U_{T S} \times t\right)$, dalelè gali būti ir vèl iškvèpta. Kadangi tikimybė, kad mažiausios aerozolio dalelès vèl bus iškvèptos, yra atvirkščiai proporcingos depozicijai 


\section{Farmakoterapija}

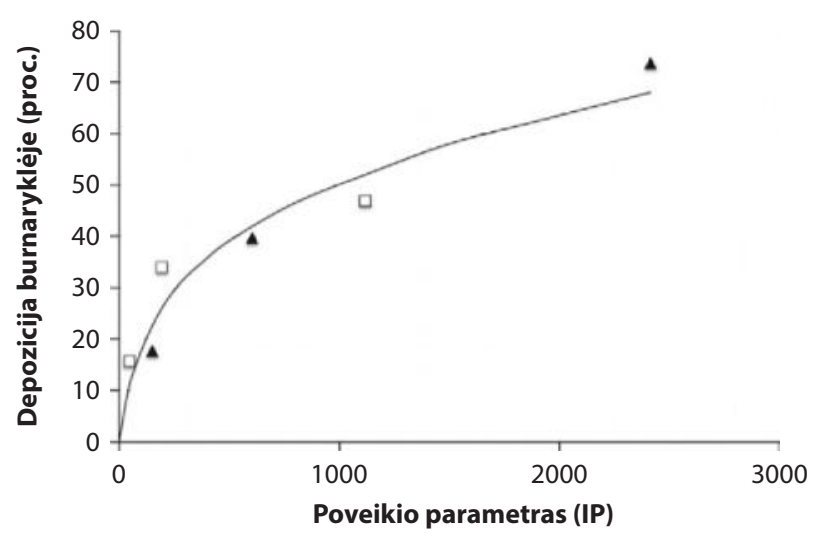

$\square$ Srovès greitis $31 \mathrm{l} / \mathrm{min}$. $\quad \mathbf{\Delta}$ Srovès greitis $67 \mathrm{l} / \mathrm{min}$.

2 pav. Depozicija burnaryklèje procentais, apskaičiuota poveikio parametru $\left(I P=\rho \times D^{2} \times \Phi\right)$

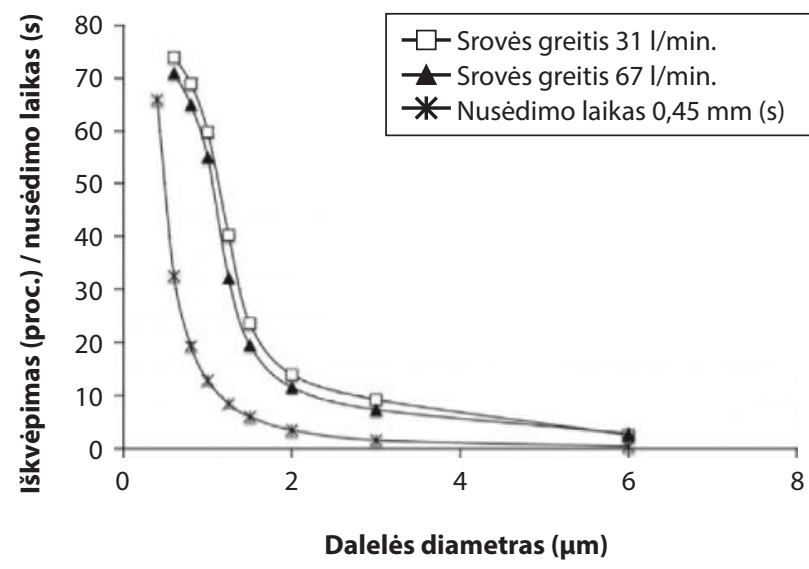

3 pav. Iškvèpimas (proc.) ir laikas (sek.), per kurị sumažèja atstumas iki 0,45 mm (lygus bronchiolès diametrui), atsižvelgiant i i ikvepiamo vaisto dalelių skersmenị

dèl sedimentacijos, iškvepiama frakcija rodo tą pačią dalelès diametro priklausomybę kaip ir laikas, per kurị ji pasieks kvejpavimo takus. $3 \mu \mathrm{m}$ diametro dalelèms reikia tik 1,6 sek. išgyvenamumo trukmès, kad pasiektų kvèpuojamąsias bronchioles $(0,45 \mathrm{~mm})$, tačiau šis laikas prailgeja iki 12,8 sek. ir 511 sek. dalelèms, kurios yra 1,0 ir $0,1 \mu \mathrm{m}$, atitinkamai. 3 pav. pateikiamas laikas, per kurị 0,4-0,6 $\mu \mathrm{m}$ dalelès nukeliauja atstumą, lygu kvèpuojamųjų bronchiolių diametrui. Šis santykis rodo staigų mažesnių nei mikrometras dalelių padidejjimą per šį laiką. Tokioms mažoms dalelèms laikas, skirtas praeiti per kvėpuojamųjų bronchiolų skersmeni, tampa reikšmingai ilgesnis nei vidutinè kvèpavimo sulaikymo pauzè. 3 pav. taip pat rodo $1,5,3,0$ ir $6,0 \mu \mathrm{m}$ daleliu iškvejpimo frakcijas ir santykị tarp iškvèpimo frakcijos bei dalelių diametro, kuris kryptingai panašus ị šiu dalelių diametro nusèdimo greitị.

\section{SKIRTINGI INHALIATORIAI - SKIRTINGAS VAISTO PASISKIRSTYMAS PLAUČIUOSE}

A. H. Boer tyrimų apžvalgoje aptariami DPI susideda iš tų pačių komponentų: IGK ir IVBA, tačiau yra skirtingo dizaino ir skirtingų fizikinių savybių. TurbuHaler ${ }^{\oplus}$ ir NEXThaler ${ }^{\oplus}$ yra daugiadoziai inhaliatoriai, turintys dozès skaičiuoklị. Seretide Diskus ${ }^{\circ}$ yra dozuotų miltelių inhaliatorius, kuriame ant folijos juostelès esančių pūslyčių yra fiksuotos vaistų dozès. NEXThaler ${ }^{\oplus}$ sudètyje yra magnio stearato, kuris veikia kaip užpildas ir reguliuoja lipnumą. Ši medžiaga leidžia vaisto dalelèms lengviau atsiskirti nuo nešančiųjų kristalų ịkvèpimo metu, o dalis šios medžiagos, kuri tirpsta vandenyje, yra įkvepiama. Tik TurbuHaler ${ }^{\oplus}$ ir NEXThaler ${ }^{\circledR}$ inhaliatoriai turi specifini miltelių dispersijos principą generuoti aerozolị esant ¡kvèpimo srovei.

DPI prietaisų pasipriešinimas oro srautui ir srovès greitis, atitinkantis slègio kritimą iki $4 \mathrm{kPa}$, pavaizduotas 2 lenteleje. Duomenys rodo, kad TurbuHaler ${ }^{\circ}$ ir NEXThaler ${ }^{\circ}$ yra nuo vidutinio iki aukšto įkvepiamo oro pasipriešinimo (esant $4 \mathrm{kPa}$, srauto greitis 59 l/min.), tuo tarpu kai Seretide Diskus ${ }^{\oplus}(75,21 / \mathrm{min}$.) yra vidutinio pasipriešinimo. Vis dèlto šie pasipriešinimo skirtumai tarp visų prietaisų yra santykinai maži ir beveik neturi jokios ịtakos vienodo dydžio dalelių nusèdimui (depozicijai).

Dozès, patenkančios it plaučius, proporcija yra labai svarbi, tačiau $\mathrm{FPF}<5 \mu \mathrm{m}$ patenkančioje dozejje laikoma tiesioginiu inhaliatoriaus matavimo vienetu depozicijai plaučiuose. 4 pav. pateikiama procentinè IGK ir IVBA vaisto frakcijos išraiška (remiantis vaisto charakteristiku santrauka) atitinkamai su didžiausių ir mažiausių reikšmių pasiskirstymo reikšmèmis. Diskus ${ }^{\oplus}$, TurbuHaler ${ }^{\circ}$ ir NEXThaler rodo beveik nepriklausomą nuo slègio kitimą smulkiosioms dalelèms. Priešingai, didejant TurbuHaler ${ }^{\circledast}$ ikvèpimo pastangoms, didejja smulkiųju dalelių frakcija. Padidejjimas yra ryškiausias tarp 2 ir 4 $\mathrm{kPa}$, todèl yra pageidautinas siekiant kompensuoti vaisto nusėdimą burnaryklejje bei nusèdimą pagrindiniuose kvépavimo takuose esant didesniam srautui.

Skirtumai tarp inhaliatorių egzistuoja ne tik dèl bendros FPF $<5 \mu \mathrm{m}$, tačiau ir dèl pačios šiu dalelių frakcijos struktūros. Didžią̧ą NEXThaler dalį sudaro dalelès $<1 \mu \mathrm{m}$ ( 5 pav.), trečdali sudaro $\mathrm{FPF}<5 \mu \mathrm{m}$, prisidedančios prie šio prietaiso išskiriamo aerozolio mažo MMAD. Kituose inhaliatorių aerozoliuose dalelių, mažesnių nei mikrometras, frakcija yra daug mažesnè, o aerozoliuose, pvz., Diskus ${ }^{\oplus}$ ši dalis beveik nereikšminga. $\mathrm{FPF}<5 \mu \mathrm{m}$ skirtumai tarp inhaliatoriu ypač atsispindi frakcijos 1-3 $\mu \mathrm{m}$ skirtumuose. Šios frakcijos daliai, tiesiogiai susijusiai su depozicija plaučiuose, TurbuHaler ${ }^{\oplus}$ ir NEXThaler ${ }^{\oplus}$ rezultatai yra geriausi. Mažiausiai ryškūs skirtumai stambiausios, t. y. 3-5 $\mu \mathrm{m}$ dalelių frakcijos. Tai yra svarbiau IVBA nei IGK vaisto komponentui, nes žinoma, kad tokio diametro dalelès turi geresnị bronchus plečiamąji poveikị esant nedideliam įkvèpimo srautui.

FPF skirtumai daro didesnę įtaką vaisto pasiskirsty- 
2 lentelè. Pasipriešinimas oro srautui ir srovès greitis (esant 5 kPa slègiui)

\begin{tabular}{|c|c|c|c|c|c|c|}
\hline \multirow{2}{*}{ DPI } & \multicolumn{3}{|c|}{ Pasipriešinimas oro srovei $\left(0,5 \mathrm{kPa} \min . \mathrm{L}^{-1}\right)$} & \multicolumn{3}{|c|}{ Srovès greitis, esant $4 \mathrm{kPa}\left(\min . \mathrm{L}^{-1}\right)$} \\
\hline & Vidurkis & Mažiausia reikšmé & Didžiausia reikšmė & Vidurkis & Mažiausia reikšmè & Didžiausia reikšmè \\
\hline SY-TU & 0,0340 & 0,0338 & 0,0343 & 58,8 & 58,3 & 59,2 \\
\hline SE-DI & 0,0266 & 0,0240 & 0,0295 & 75,2 & 83,8 & 67,8 \\
\hline FO-NE & 0,0339 & 0,0334 & 0,0345 & 59,0 & 59,9 & 58,0 \\
\hline
\end{tabular}

Santrumpos: DPI - sausujų miltelių inhaliatorius; FO-NE - Foster ${ }^{\oplus}$ NEXThaler ${ }^{\oplus}$; SE-DI - Seretide ${ }^{\circledast}$ diskas; SY-TU - Symbicort ${ }^{\oplus}$ TurbuHaler $^{\oplus}$.

mui kvèpavimo takuose, ịskaitant ir burnaryklę. NEXThaler didžiąją dalị sudaro vaisto dalelès, mažesnès nei mikrometras. Aerozolio dalelès $<1 \mu \mathrm{m}$ veiksmingai praeina per burnaryklę ir nukeliauja $\mathfrak{i}$ bronchų medị. Tačiau šios dalelès turi labai mažą depozicijos tikimybę, nes yra vèl iškvepiamos dèl eksponentiškai mažéjančio nusẻdimo greičio mažèjant aerodinaminiam dalelès skersmeniui. 1-3 $\mu \mathrm{m}$ dalelès turi didesnị ryšį bendrai depozicijai plaučiuose ir šie akivaizdūs šio skersmens dalelių dydžiai tarp skirtingų inhaliatorių, kurių pasipriešinimą oro srovei galima palyginti, galètų būti geras rodiklis, renkantis inhaliatorių.

\section{IŠVADOS}

Staigus iškvèpimo frakcijos didejimas, mažéjant dalelių diametrui iki mažesnio diametro nei $1 \mu \mathrm{m}$, rodo, kad tokio diametro dalelès nèra tinkamos inhaliacijai. Didelès masės dalelių, t. y. mažesnių nei mikrometras, frakcijos prisideda prie mažesnio aerozolio MMAD, tačiau tokios dalelès taip pat yra iškvepiamos pakartotinai. Tokią išvadą galima daryti iš in vivo monodispersinių dalelių depozicijos klinikinių tyrimų. Vertinant atliktus tyrimus, apibrèžimas "mažesnis nei mikrometras“ yra kiek tikslesnis ir aiškesnis nei terminas „itin smulkus“. Depozicija plaučiuose išreikšta procentais, vertinant ịvairius depozicijos plaučiuose modelius, ịrodè, kad dalelès, kurių dydis yra $1-3 \mu \mathrm{m}$, yra labiausiai tinkamos bendrajai depozicijai

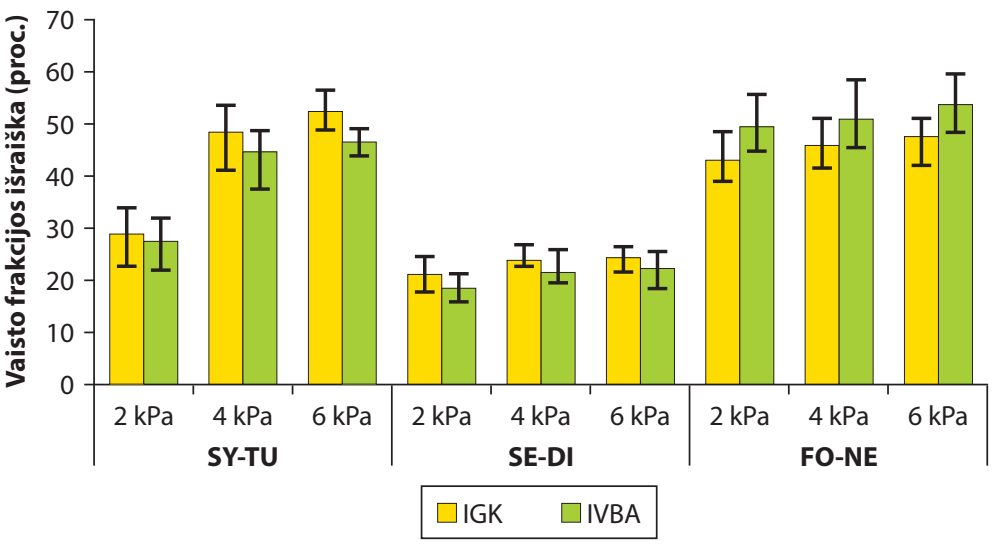

4 pav. Patenkančiu smulkiuju daleliu vaisto frakcijos išraiška (proc.) (FPF $<5 \mu \mathrm{m}$ ) trijuose skirtinguose DPI, esant skirtingiems slègiams. Pasiskirstymo stulpeliai rodo mažiausią ir didžiausią reikšmes

Santrumpos: FO-NE - Foster ${ }^{\circledast}$ NEXThaler ${ }^{\circledast}$; FPF - smulkiujų dalelių frakcija; IGK - inhaliuojamieji gliukokortikoidai; IVBA -ilgo veikimo $\beta_{2}$ agonistai; SE-DI - Seretide ${ }^{\circledast}$ diskas; SY-TU - Symbicort ${ }^{\oplus}$ TurbuHaler ${ }^{\circledast}$.

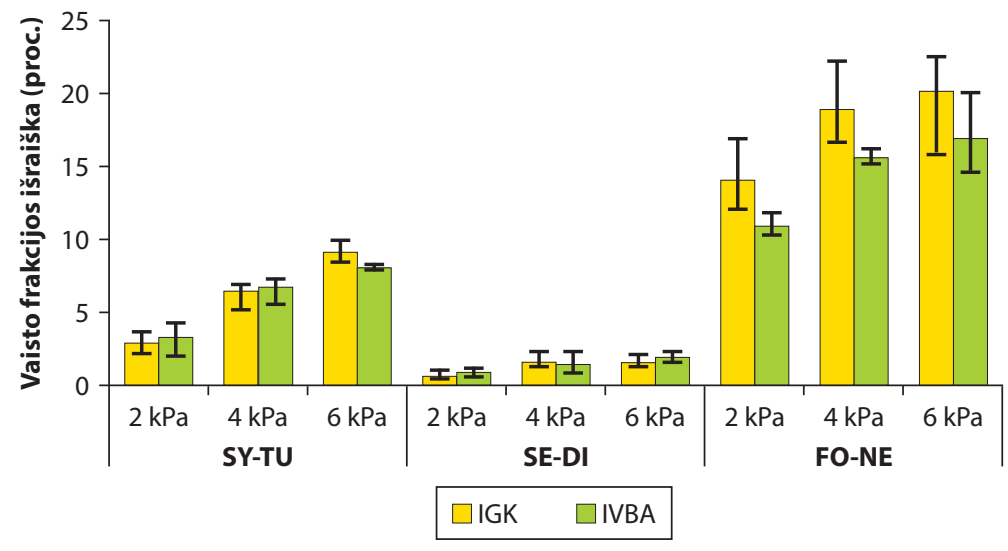

5 pav. Dalelių, mažesnių nei mikrometras, frakcijos dalis skirtinguose inhaliatoriuose (proc.) (FPF $<1 \mu \mathrm{m})$

Santrumpos: FO-NE - Foster ${ }^{\oplus}$ NEXThaler ${ }^{\oplus}$; FPF - smulkiuju dalelių frakcija; IGK - inhaliuojami gliukokortikoidai; IVBA - ilgo veikimo $\beta_{2}$ agonistai; SE-DI - Seretide ${ }^{\oplus}$ diskas; SY-TU - Symbicort ${ }^{\circledast}$ TurbuHaler ${ }^{\oplus}$. plaučiuose, kai jos yra įkvepiamos vidutiniu srovès greičiu (vidutiniškai - 30-60 l/min.) ir turi pakankamai laiko nusèsti periferiniuose kvèpavimo takuose.

Tarp išskiriamų smulkiųjų dalelių frakcijų (FPF $<1 \mu \mathrm{m})$ ir kiek reikšmingesnių 1-3 $\mu \mathrm{m}$ skersmens dalelių yra didelis skirtumas. Apžvelgus daugeli veiksnių, TurbuHaler ${ }^{\circledR}$ ir NEXThaler ${ }^{\bullet}$ yra daug pranašesni, lyginant su Diskus ${ }^{\oplus}$. Priešingai, didžioji 3-5 $\mu \mathrm{m}$ frakcijos dalis yra panašios reikšmės. Atsižvelgiant

ị šiuos smulkiụjų dalelių skirtumus, būtų galima tikètis reikšmingo skirtumo depozicijai plaučiuose ir vaisto pasiskirstymo kvèpavimo takuose, kai inhaliatoriai naudojami taisyklingai.

Parengta pagal straipsni: Boer AH, Gjaltema D, Hagedoorn P, Henderik W. Can 'extrafine' dry powder aerosols improve lung deposition? Eur J Pharm Biopharm. 2015;96:143-51. 